\title{
Glyphosate-resistant hairy fleabane documented in the Central Valley
}

\author{
by Anil Shrestha, Bradley D. Hanson \\ and Kurt J. Hembree
}

In recent years, growers and pest consultants have reported poor control of the weed hairy fleabane in some areas of the Central Valley. Hairy fleabane seeds were collected from Esparto, Fresno and Reedley, Calif., and greenhouse-grown seedlings were treated at several different glyphosate rates and compared with an untreated control. None of the Esparto or Fresno plants survived glyphosate rates greater than 0.78 pounds acid equivalent per acre (Ib ae/ac), while some of the plants from Reedley survived even the highest rate of glyphosate tested $(12.4 \mathrm{lb}$ ae/ac). The dose required to reduce plant dry weights by $50 \%$ (GR $\left.R_{50}\right)$ of the Esparto plants ranged from 0.28 to $0.30 \mathrm{lb}$ ae/ac, whereas the $\mathbf{G R}_{50}$ of the Fresno and Reedley plants ranged from 0.26 to 0.61 and 0.92 to $2.88 \mathrm{lb}$ ae/ac, respectively. This study showed that the hairy fleabane plants from Reedley were much more tolerant of glyphosate than either of the other two biotypes and, based on the $G R_{50}$, the level of resistance ranged from 3- to 10-fold greater.

Tairy or flax-leaved fleabane is a ma1 jor weed infesting roadsides, ditchbanks, orchards, vineyards and fallow areas in California. This weed belongs to the Asteraceae family and is an annual or short-lived perennial native to South America (Noyes 2000). At the seedling stage, hairy fleabane (Conyza bonariensis) looks very similar to horseweed (Conyza canadensis) and can often be found growing in the same locations. The most common methods used to control hairy fleabane in California include the use of pre- and postemer-

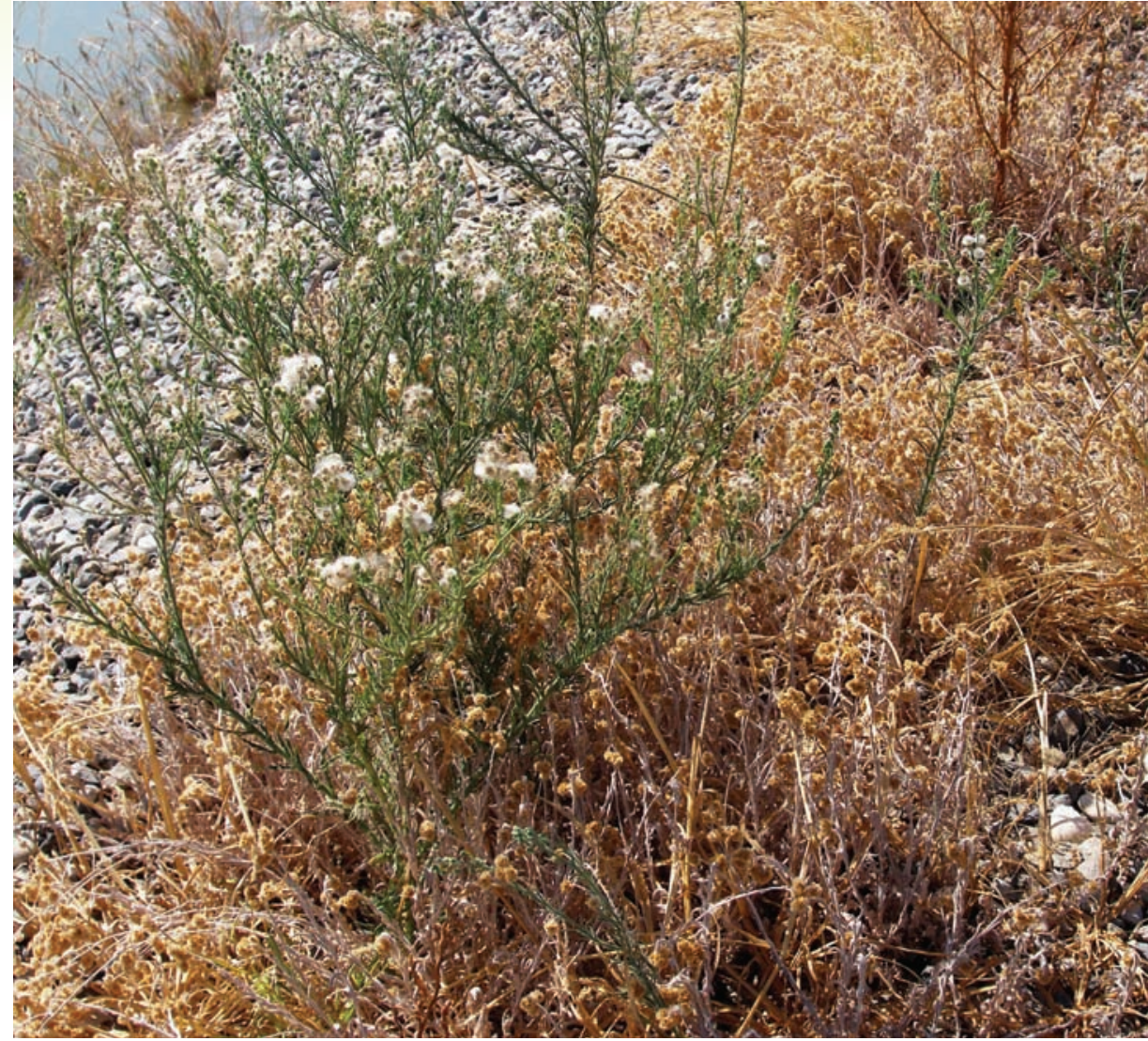

Hairy fleabane plants survived glyphosate (Roundup Weathermax) applications on a reservoir bank in Fresno County. Over-reliance on herbicides with the same mode of action often leads to resistance.

gent herbicides, fall and/or spring cultivation, and hand-pulling. Generally, broad-spectrum postemergent herbicides, primarily glyphosate (Roundup), are used to control these weeds in orchards, vineyards and noncrop areas in California (Shrestha et al. 2007).

Glyphosate is considered the world's most important herbicide because it provides broad-spectrum weed control and has favorable environmental characteristics and low mammalian toxicity (Baylis 2000; Woodburn 2000). These characteristics, combined with its cost-effectiveness, have led to frequent applications of glyphosate in perennial cropping systems and noncrop areas in California (Shrestha et al. 2007). However, reliance on herbicides with the same mode of action for extended periods can contribute to weed shifts and the selection of biotypes with resistance to herbicides (Christoffers 1999; Holt 1992) (see page 86). As a result of this selection pressure, cases of glyphosate-resistant rigid rye-grass (Lolium rigidum) (Heap 2008; Simarmata et al. 2005) and horseweed (Shrestha et al. 2007) have been reported in California orchards and noncrop areas, respectively.

In recent years, poor control of hairy fleabane with glyphosate has been observed in orchards, vineyards and noncrop areas of California. Since glyphosate-resistant horseweed has locations (Shrestha et al. 2007), and glyphosate-resistant hairy fleabane has been reported in perennial crops in Spain (Urbano et al. 2007), we suspected glyphosate resistance in hairy fleabane after observing weeds that were not killed by labeled rates of glyphosate (escapes) at several sites. The objective of our study was to test for glyphosate resistance in hairy fleabane been documented in similar California 


\section{It is very likely that glyphosate-resistant hairy fleabane is present in cropped areas, particularly in orchards and vineyards of the Central Valley.}

plants grown from seeds collected in perennial crop and noncrop locations around central California.

\section{Greenhouse studies}

Seeds of hairy fleabane were collected in 2006 from a suspected glyphosate-resistant roadside population in Reedley $\left(36^{\circ} 29^{\prime} 15 \mathrm{~N}\right.$; $119^{\circ} 24^{\prime} 10$ W). Seeds of suspected glyphosatesusceptible populations were collected from a vineyard in western Fresno $\left(36^{\circ} 47^{\prime} 58 \mathrm{~N} ; 119^{\circ} 57^{\prime} 16 \mathrm{~W}\right)$ and a noncrop area near Esparto (38 $40^{\prime} 09 \mathrm{~N}$; $122^{\circ} 01^{\prime} 11 \mathrm{~W}$ ), where effective control is usually obtained with a labeled rate (22 fluid ounces per acre [fl oz/ac], i.e., 0.78 pounds acid equivalent per acre [lb ae/ac]) of glyphosate formulated as Roundup Weathermax.

Seeds were stored in a refrigerator in the laboratory at $40^{\circ} \mathrm{F}$ over the winter, planted in plastic germination trays in the laboratory in spring, and moved to a greenhouse following emergence. The day and night temperatures in the greenhouse were set at $75^{\circ} \mathrm{F}$ to $80^{\circ} \mathrm{F}$ and $60^{\circ} \mathrm{F}$ to $65^{\circ} \mathrm{F}$, respectively. No supplemental lighting was used. When the seedlings developed two to three leaves, they were transplanted into plastic pots (6 inches deep, 4 inches wide) containing a commercial potting mix.

Experiments comparing the Esparto and Reedley populations and Fresno and Reedley populations were conducted separately and repeated. All the experiments were conducted between May and August. The experimental design was a completely randomized design with five replications. Each pot with a seedling from each location was an experimental unit. The plants were watered regularly and fertilized twice during the growing season with a commercial fertilizer (MiracleGro).

The seedlings were treated with glyphosate (formulated as Roundup Weathermax) at rates of 0 (untreated), $0.19,0.39,0.78,1.55,3.1,6.2$ and $12.4 \mathrm{lb}$ ae/ac. These rates correspond to $0,5.5$, $11,22,44,88,176$ and $352 \mathrm{fl} \mathrm{oz} / \mathrm{ac}$ of Roundup Weathermax. Treatments were applied with a moving-nozzle cabinet sprayer calibrated to deliver 17.7 gallons per acre through a single 8002 flat fan nozzle positioned 22 inches above the target plants.

Growth stage (leaf numbers) of the treated plants differed between experiments due to the duration of growth before treatment and conditions in the greenhouse. In the experiments comparing plants from Esparto and Reedley, the plants were treated with glyphosate at the 8-to-11-leaf stage and 18-to-22leaf stage in the first and second runs of the experiment, respectively. In the experiments comparing the Fresno and Reedley plants, the plants were treated at the 12-to-15-leaf stage and 17-to-23-leaf stage in the first and second runs of the experiment, respectively.

Mortality and aboveground dry weight of the treated plants were recorded 2 weeks after glyphosate application. The plants were designated as "dead" when the aboveground plant parts showed no traces of green tissue (necrosis). All the plants, including the ones that died, were clipped at the surface of the soil, placed in separate paper bags, dried to constant weight in a forced-air oven at $140^{\circ} \mathrm{F}$, and their dry weights were recorded. Some extra plants in each treatment were maintained up to a month after glyphosate application for visual assessments of damage and regrowth. Dry weights of the plants were expressed as percentage of control. Mortality data were subjected to analysis of variance using GLM procedures in SAS with an alpha level of 0.05 . Dry weight data (\% of control) were regressed against glyphosate dose, and a four-parameter logistic curve was fit using SigmaPlot with the following equation:

$$
Y=\min +\frac{\max -\min }{1+10\left(\mathrm{GR}_{50}-\mathrm{x}\right)}
$$

where $Y$ is plant dry weight (\% of control), $\min$ is the minimum response limit, max is the maximum response limit, $G R_{50}$ is the glyphosate dose required to reduce dry weight by $50 \%$ and $x$ is the concentration of glyphosate.
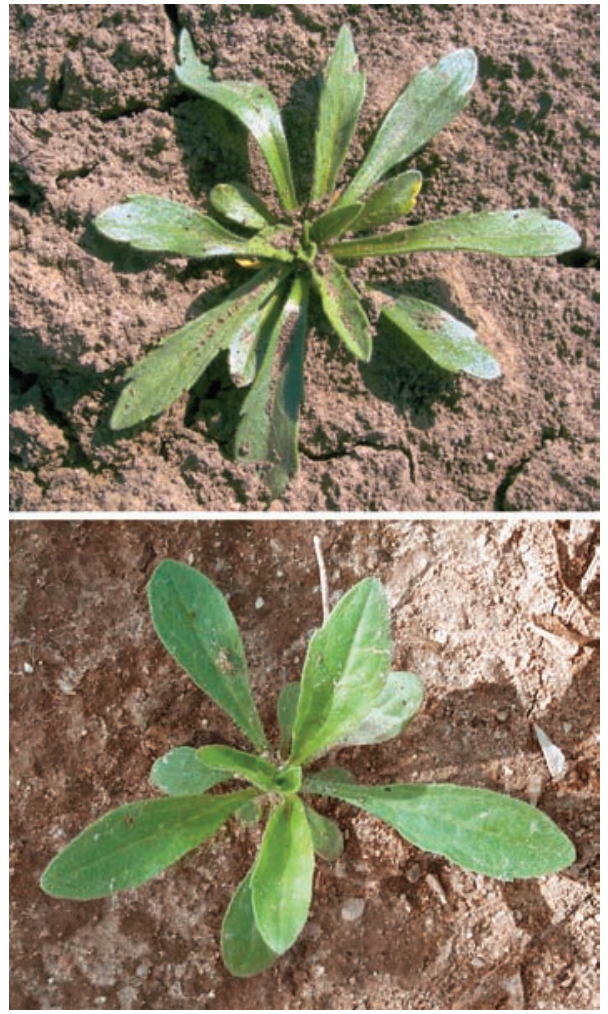

Seedlings of, top, hairy fleabane and, bottom, horseweed. Populations of both weeds have now been shown to be resistant to glyphosate, a commonly used herbicide.

There were no interactions $(P>$ 0.05 ) between the glyphosate rate and experimental run for plant mortality. However, in the biomass data, interactions $(P<0.05)$ occurred between glyphosate rate and experimental run. Therefore, data for plant mortality were combined for experimental rounds, whereas data for plant dry weight were analyzed separately for each run.

\section{Plant mortality and dry weight}

Plant mortality. In both experiments, all the seedlings from Fresno and Esparto were killed with a glyphosate rate of $1.55 \mathrm{lb}$ ae/ac (figs. 1A, $1 B)$. However, this was higher than the labeled rate $(0.78 \mathrm{lb}$ ae/ac) for hairy fleabane control. In both experiments, about $50 \%$ of the hairy fleabane plants from the suspected glyphosatesusceptible populations of Esparto and Fresno were able to survive the 


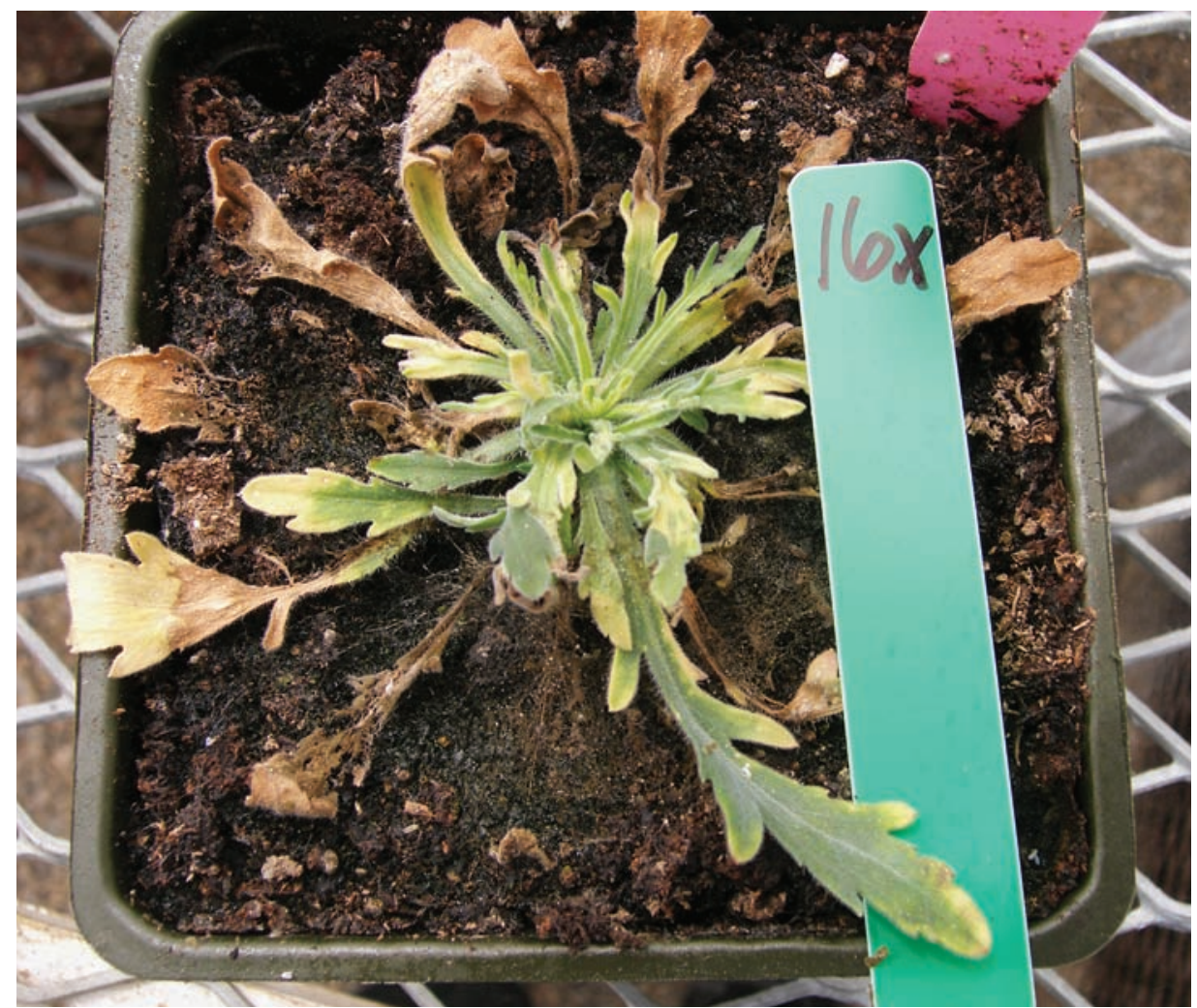

In this study, glyphosate-resistant hairy fleabane recovered from injury 4 weeks after glyphosate was applied at 16 times the recommended rate.

labeled rate. This indicates that high chances of hairy fleabane escapes are present with the labeled rate even when they are sprayed as early as the 8-to-11-leaf stage. Depending on the growth stage, plants from Reedley required glyphosate rates of $6.2 \mathrm{lb}$ ae/ ac or higher to kill $50 \%$ of the plants. In the experiment comparing Fresno and Reedley plants (fig. 1B), about $40 \%$ of the plants from Reedley survived a glyphosate rate of $12.4 \mathrm{lb}$ ae/ac, which was 16 times the recommended rate.

These results showed that the plants from Reedley were glyphosateresistant. Although the effect of growth stage on the level of resistance was not evaluated in this study, we suspect that the level of resistance could vary with growth stage. Interactions between glyphosate rate and plant growth stage have been reported in horseweed (Shrestha et al. 2007). The study also showed that although the hairy fleabane populations of Fresno and Esparto were generally susceptible to glyphosate, some plants escaped the labeled rate, and a glyphosate application at $1.55 \mathrm{lb}$ ae/ac was required to kill these plants.
Plant shoot dry weight. Plant shoot dry weight expressed as percentage of untreated control varied between experiments (figs. 2 and 3). This may have been due to differences in the growth stages (leaf numbers) between the experiments. Urbano et al. (2007) have also reported that the glyphosate response of resistant and susceptible hairy fleabane plants was dependant on phenological stage. The $\mathrm{GR}_{50}$ of the glyphosate-susceptible and glyphosate-resistant plants increased with growth stage in their study. In our study, the $\mathrm{GR}_{50}$ of the Esparto and Reedley plants ranged from 0.28 to 0.30 and 0.92 to $2.88 \mathrm{lb}$ ae/ac, respectively (fig. 2). Similarly, the $\mathrm{GR}_{50}$ of the Fresno and Reedley plants ranged from 0.26 to 0.61 and 1.62 to $1.79 \mathrm{lb}$ ae/ac, respectively (fig. 3).

Based on these $\mathrm{GR}_{50}$ values, the hairy fleabane plants from Reedley showed at least a 3-fold level of repopulations. However, the level of resistance ranged up to 10 -fold depending on the growth stage of the plants at application. This result is consistent with the findings of Urbano et sistance compared to the susceptible

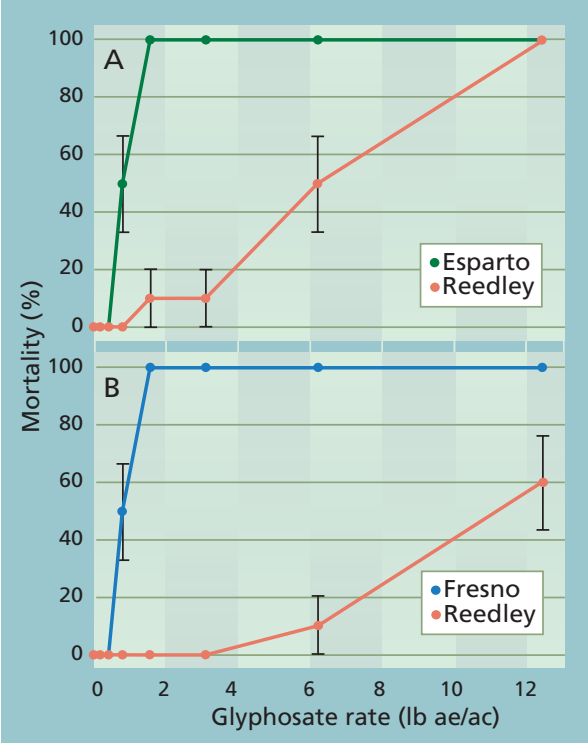

Fig. 1. Average percent mortality ( \pm SE) of hairy fleabane plants sprayed with different glyphosate rates from (A) Esparto and Reedley at the 8-to-11-leaf stage and 18-to-23-leaf stage and (B) Fresno and Reedley at the 12-to-15-leaf stage and 15-to-18-leaf stage.

al. (2007), who also reported a 10-fold level of resistance. A phenomenon noticed in the plants that survived the highest rates of glyphosate was the appearance of new leaves from the center of the plant. Similar symptoms were also noticed in glyphosate-resistant horseweed.

\section{Managing hairy fleabane}

This study confirmed the presence of glyphosate-resistant hairy fleabane in noncrop areas of the Central Valley. It is very likely that glyphosate-resistant hairy fleabane is also present in cropped areas, particularly in orchards and vineyards of the Central Valley, because the windborne seeds of hairy fleabane can travel considerable distances with wind currents. Our results also indicated that the current labeled rate of glyphosate may not be sufficient to consistently control glyphosate-susceptible hairy fleabane populations at the early rosette stages. The chances of glyphosate escapes will be greater if applications are made after the plants have developed more than 10 leaves.

Because hairy fleabane can emerge in multiple flushes in late fall, late winter, 


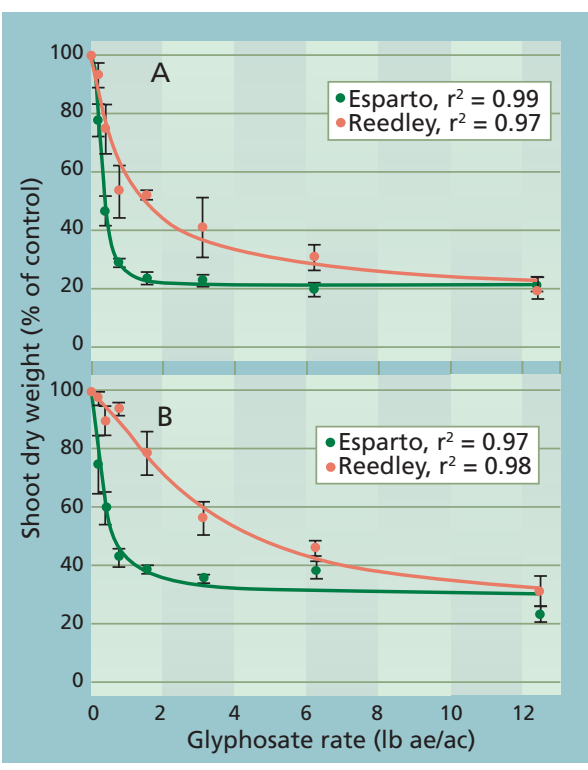

Fig. 2. Average shoot dry weights ( $\pm \mathrm{SE}$ ) of Esparto and Reedley hairy fleabane plants (expressed as percentage of untreated control) under different glyphosate rates in the (A) first (8-to-11-leaf stage) and (B) second (18-to-22leaf stage) experimental run.

early spring and spring, several applications of the herbicide may be needed if a glyphosate-alone weed management strategy is used. This will decrease the cost-effectiveness of the weed management strategy and will further increase the selection of glyphosate-resistant weeds. Therefore, we recommend that multiple tactics, including applying pre-emergent herbicides and combining glyphosate with other postemergent herbicides, be used to manage hairy fleabane in the Central Valley.

A. Shrestha is Integrated Pest Management Weed Ecologist, UC Statewide IPM Program, UC Kearney Agricultural Center, Parlier; B.D. Hanson is Research Agronomist, U.S. Department of Agriculture/Agricultural Research Service, San Joaquin Valley Agricultural Sciences Center, Parlier; and K.J. Hembree is Farm Advisor, UC Cooperative Extension, Fresno County. We thank Tom Lanini, Weed Ecologist, UC Davis, for providing us with hairy fleabane seeds from Esparto. We also thank Thomas Wang and Ivan Ramirez, students of California State University, Fresno, for their assistance in this project. We gratefully acknowledge the support of Laura Van der Staay, UC Kearney Research and Extension Center, Parlier, with the greenhouse operations during this study.

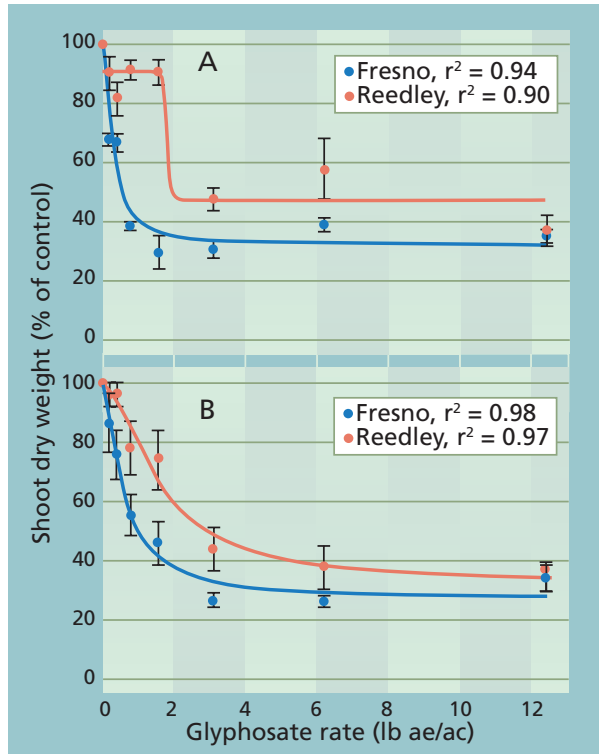

Fig. 3. Average shoot dry weight $( \pm S E$ ) of Fresno and Reedley hairy fleabane plants (expressed as percentage of untreated control) under different glyphosate rates in the (A) first (12-to-15-leaf stage) and (B) second (17-to-23leaf stage) experimental run.

\section{References}

Baylis AD. 2000. Why glyphosate is a global herbicide. Strengths, weaknesses and prospects. Pest Manag Sci 56:299-308

Christoffers MJ. 1999. Genetic aspects of herbicideresistant weed management. Weed Technol 13:647-52

Heap I. 2008. International survey of herbicide resistant weeds. www.weedscience.org

Holt JS. 1992. History of identification of herbicideresistant weeds. Weed Technol 6:615-20.

Noyes RD. 2000. Biogeographical and evolutionary insights on Erigeron and allies (Asteraceae) from ITS sequence data. Plant System Evolu 220:93-114.

Shrestha A, Hembree KJ, Va N. 2007. Growth stage influences level of resistance in glyphosateresistant horseweed. Cal Ag 61(2):67-70.

Simarmata M, Bughrara S, Penner D. 2005. Inheritance of glyphosate resistance in rigid ryegrass ( $L O-$ lium rigidum) from California. Weed Sci 53:615-9.

Urbano JM, Borrego A, Torres V, et al. 2007 Glyphosate-resistant hairy fleabane (Conyza bonariensis) in Spain. Weed Technol 21:396-401.

Woodburn A. 2000. Glyphosate production, pricing and use worldwide. Pest Manag Sci 56:309-12.

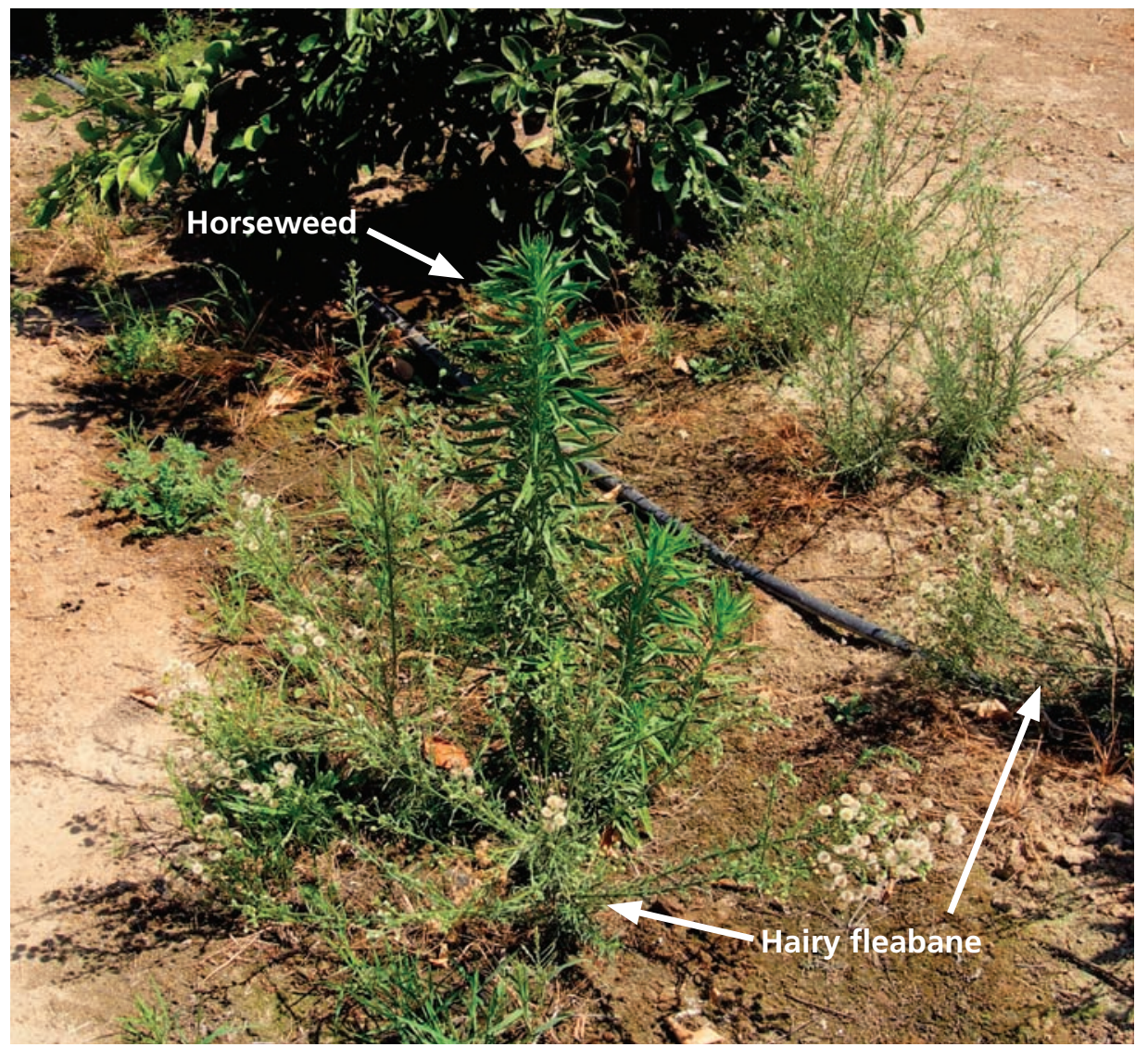

Horseweed and hairy fleabane grow side-by-side in a Fresno County citrus orchard. The use of multiple tactics can prevent further development of herbicide resistance in these weeds. 